\title{
Morphometric analysis of a drainage basin using geographical information system in Gilgel Abay watershed, Lake Tana Basin, upper Blue Nile Basin, Ethiopia
}

\author{
Alemsha Bogale ${ }^{1}$ \\ Received: 1 May 2020 / Accepted: 9 June 2021 / Published online: 24 June 2021 \\ (C) The Author(s) 2021
}

\begin{abstract}
GIS and remote sensing approach is an effective tool to determine the morphological characteristics of the basin. Gilgel Abay watershed is stretched between latitude $10.56^{\circ}$ to $11.22^{\circ} \mathrm{N}$ and longitude $36.44^{\circ}$ to $37.03^{\circ} \mathrm{E}$ which is one major contributing river of Lake Tana which is the source of Blue Nile. The present study addressed linear and areal morphometric aspect of the watershed. The study deals with emphasis on the evolution of morphometric parameters such as stream order, stream length, bifurcation ratio, drainage density, stream frequency, texture ratio, elongation ratio, circularity ratio, and form factor ratio. The morphometric analysis of the basin revealed that Gilgel Abay is firth-order drainage basin with total of 662 drainage network, of which 511 are first order, 111 are second order, 30 are third order, 9 are fourth order, and 1 is fifth-order stream. The total length of stream is longer for first order and decrease with increasing stream order. The mean bifurcation ratio is 5.16 which is greater than the standard range, and it indicates that basin is mountainous and susceptible to flooding. Low drainage density is observed which is $0.6 \mathrm{~km}^{-2}$. It indicates that basin is highly permeable and thick vegetation cover. Areal aspect of the morphometric analysis of the basin revealed that the basin is slightly potential to flooding and soil erosion, indicating that runoff generated from the upland area of the watershed is significantly infiltrated at the gentle downstream part and contributing to groundwater potential. Further studies with the help of GIS and remote sensing with high-resolution remote sensing data integrating with ground control data in the field are more effective to formulate appropriate type of natural resource management system.
\end{abstract}

Keywords Gilgel Abay · Drainage basin · Morphometric analysis · GIS and remote sensing

\section{Introduction}

A drainage basin is a part of land where water from rainfall is contributing to a common point. It is useful element of the catchment, and all flow of water is governed by its properties (Christopher et al. 2010). GIS and remote sensing techniques are efficient tools used to analyze the hydrological process of the drainage basin (Waikar and Nilawar 2014). Drainage basin analysis is an essential used to assess and manage both ground and surface water resource. Important characteristics of the drainage basin such as shape, length of tributaries,

Alemsha Bogale

galemsha35@gmail.com

1 Department of Water Technology, Bahir Dar Polytechnic College, Bahir Dar, Ethiopia size, and slope are highly correlated with drainage basin hydrological process (Rastogi and Sharma 1976).

Drainage basin networks exhibit temporal and spatial variations. Such runoff patterns change hydrological systems and significantly change both catchment inputs and output such as stream discharge, suspended sediment, solutes and litters, and watershed characters.

Hydrological behavior of the drainage basin is used to design appropriate type of soil and water management system, prior work, erosion prone area, flood analysis, and selection of appropriate site for different water infrastructures (Dutta and Sharma 2002; Waikar and Nilawar 2014).

The drainage basins are also appropriate to consider the onsite and offsite ecology. As hydrology, water that flows in and out of the basin will deposit and pick up various elements such as sediment, nutrients, and pollutants (Oyegoke and Ifeadi 2008). They can affect both onsite and offsite ecology of the basin. Therefore, investigating the drainage 
basin process is the potential to understand the movement of water within the hydrologic cycle.

Investigating drainage pattern of the Gilgel Abay watershed which affects the hydrological process using RS and GIS tool is the objective of this paper. Understanding the drainage basin hydrology is a vital to prior and design proper type of soil and water conservation work.

\section{Materials and methods}

\section{Description of study area}

The study area (Gilgel Abay) is located in the Lake Tana Basin, upper Blue Nile, Ethiopia (Fig. 1). It is one of the largest contributing basins of the Lake Tana. The study watershed is located between latitude $10.56^{\circ}$ to $11.22^{\circ} \mathrm{N}$ and longitude $36.44^{\circ}$ to $37.03^{\circ} \mathrm{E}$. The contributing area of the watershed is $3786 \mathrm{~km}^{2}$ with the longest path of the flow of $141 \mathrm{~km}$. The higher elevation ranges are located at the southeast corner, while the remaining area is relatively uniform. The Shuttle Radar Topography Mission (SRTM) digital elevation model (DEM) shows that the elevation of

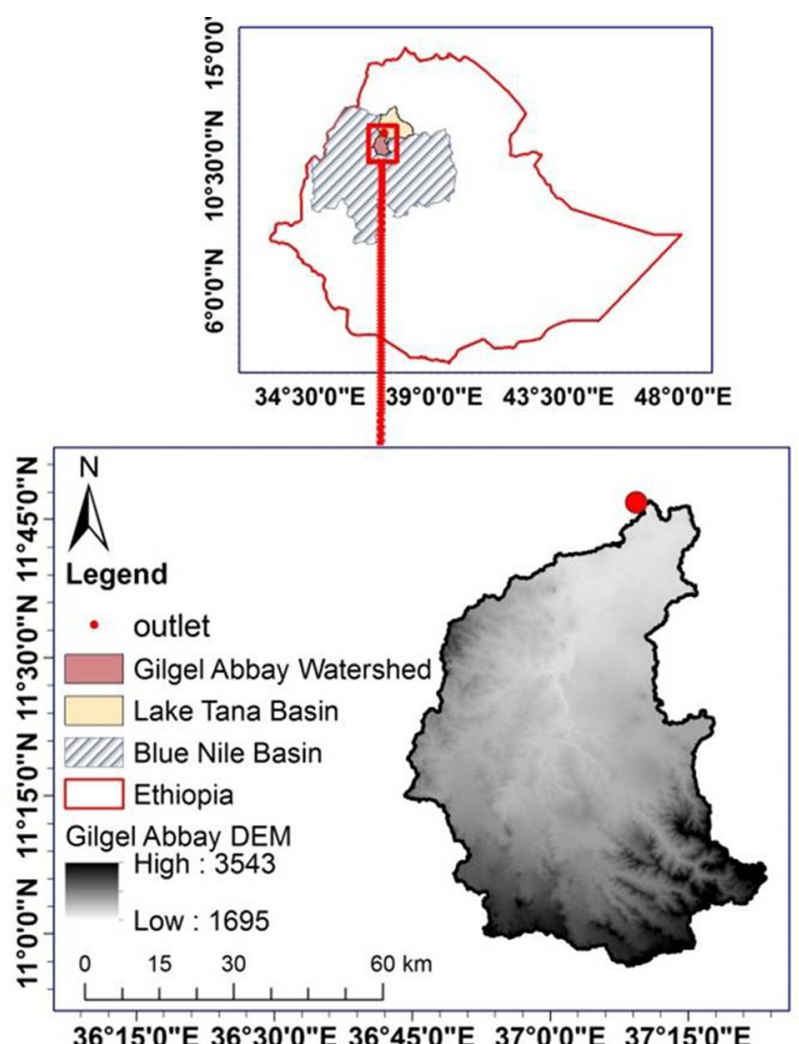

Fig. 1 Study area, Lake Tana and Blue Nile Basin and Ethiopia map ( Source: Study watershed is delineated from the DEM and the other shapefiles are obtained from the Ethiopian map server agency (http:// www.ethiogis-mapserver.org/about-us.html)) the Upper Gilgel Abay varies from $1695 \mathrm{~m}$ to $3543 \mathrm{~m}$ a.m.s.l. The main rainy season of the watershed is from June to September, while the remaining months are dry. It receives annual rainfall between 1200 and $2400 \mathrm{~mm}$. The average minimum and maximum annual temperatures vary between 3.4 and $33{ }^{\circ} \mathrm{C}$ from different meteorological stations located in the watershed. Generally speaking, the months of March through May are the hottest month, whereas the lowest temperatures occur during December and January. The upper part of the watershed is steeper slope which is about $70^{\circ}$, while the bottom part of the watershed toward the outlet is gentle slope and about $0^{\circ}$. The main land covers in the Gilgel Abay catchment are grassland, marshland, cultivated land, forest and grassland with frequent patches of shrubs, woods, trees, and cultivated lands. Cultivated land is the most dominated one.

\section{Research methodology}

To meet the objective of this study, integrating GIS and remote sensing techniques was used to analyze the morphometric characteristics of the watershed. The Shuttle Radar Topography Mission (SRTM) digital elevation model (DEM) was used to digitize study watershed and generate drainage pattern. A number of procedures were used to delineate watershed and generate stream networks. Arc GIS 10.1 software was used to analyze the morphologic characteristics of the basin. The study watershed and stream networks are automatically generated from SRTM DEM using arc toolbox in GIS 10.1. The overall methodology used to delineate and generate stream networks is as follows.

1. Collect and re-projected the DEM data to UTM zone$37 \mathrm{~N}$ coordinate system using ArcGIS arc toolbox.

2. The DEM filled out the pits using fill tool under Spatial Analyst tools of Hydrology option

3. The flow direction and accumulation map of the watershed was created using flow direction and accumulation tools of the same spatial analyst tools of hydrology option.

4. Raster calculation operation was carried out using the threshold value of 5000 to generate the stream networks, and correct location of watershed outlet was selected.

5. The watershed boundary was plotted, and the area of the watershed, length and order of the streams were calculated.

Steam ordering is usually the first step to analyze the drainage basin. It is defining the steam size based on hierarchy of its tributary. For stream ordering, Horton (1932) law slightly modified by Strahler (1952) was used. Total 
number of each order streams with its length were analyzed and recorded (Fig. 2).

The fundamental parameters, namely stream length, area, perimeter, number of streams, and basin length, are derived from drainage layer. The values of morphometric parameters, namely bifurcation ratio, drainage density, stream frequency, form factor, texture ratio, elongation ratio, and circularity ratio, were computed to analyze the behavior of the drainage basin based on the formulae suggested by Horton (1945), Miller (1953), Schumn (1956), Strahler (1964).

\section{Result and discussion}

The various morphometric parameters of the Gilgel Abay basin analyzed using GIS 10.1 are presented below.

\section{Stream network generation}

Stream networks delineated from DEM using ArcGIS Hydrology, Spatial Analyst tools are depicted (Fig. 3). The delineated streams are compared with the slope of the watershed. The slope of the watershed is steep in the upper part of the watershed and smoothly gentle in the downstream part of the watershed (Fig. 3). Large numbers of streams with short in length are generated at the steep slope, and less amount of long streams are delineated in the gentle part of the watershed, indicating that undulating topography is more susceptible to flooding and soil erosion.
Fig. 2 Watershed delineation process using ArcGIS arc toolbox

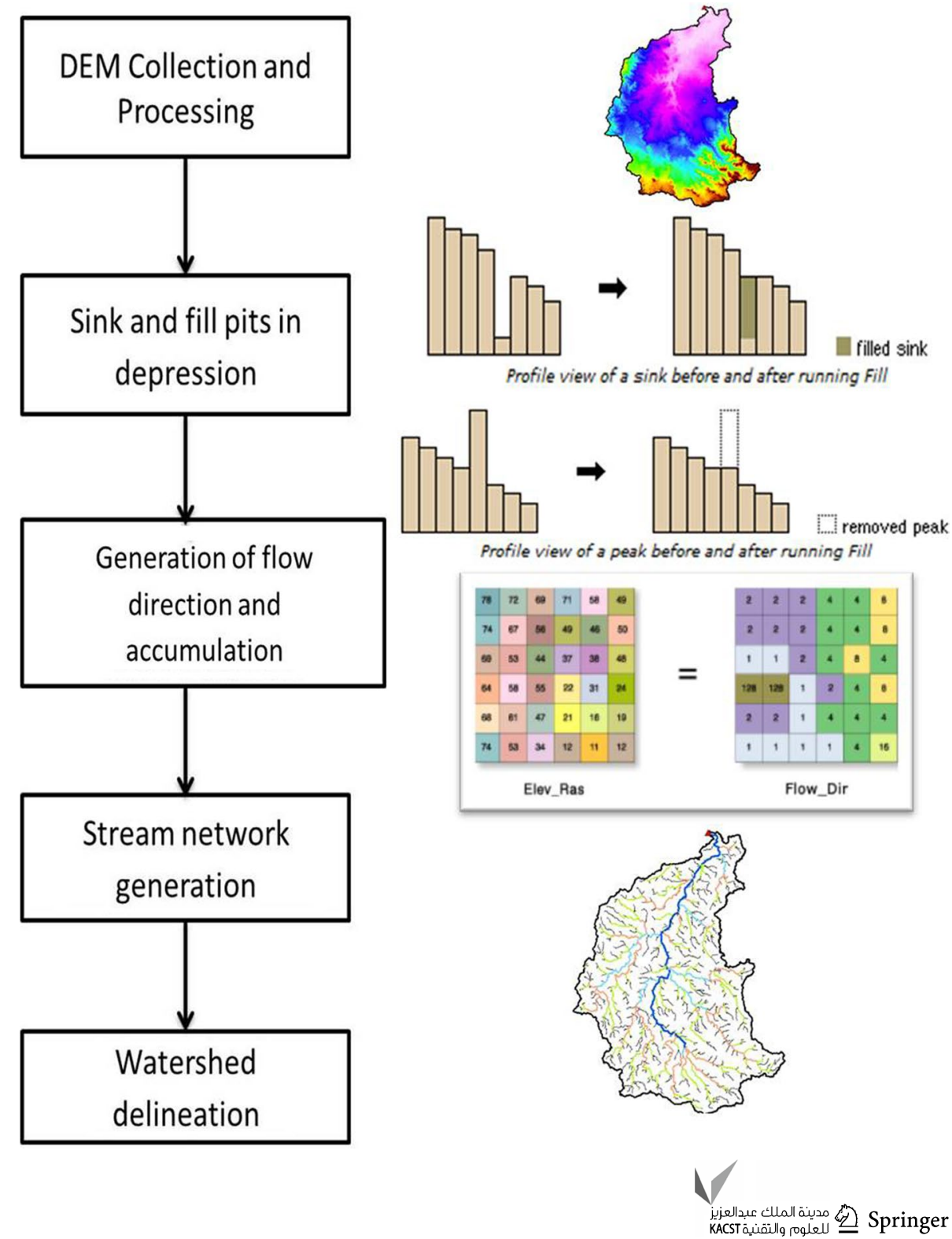



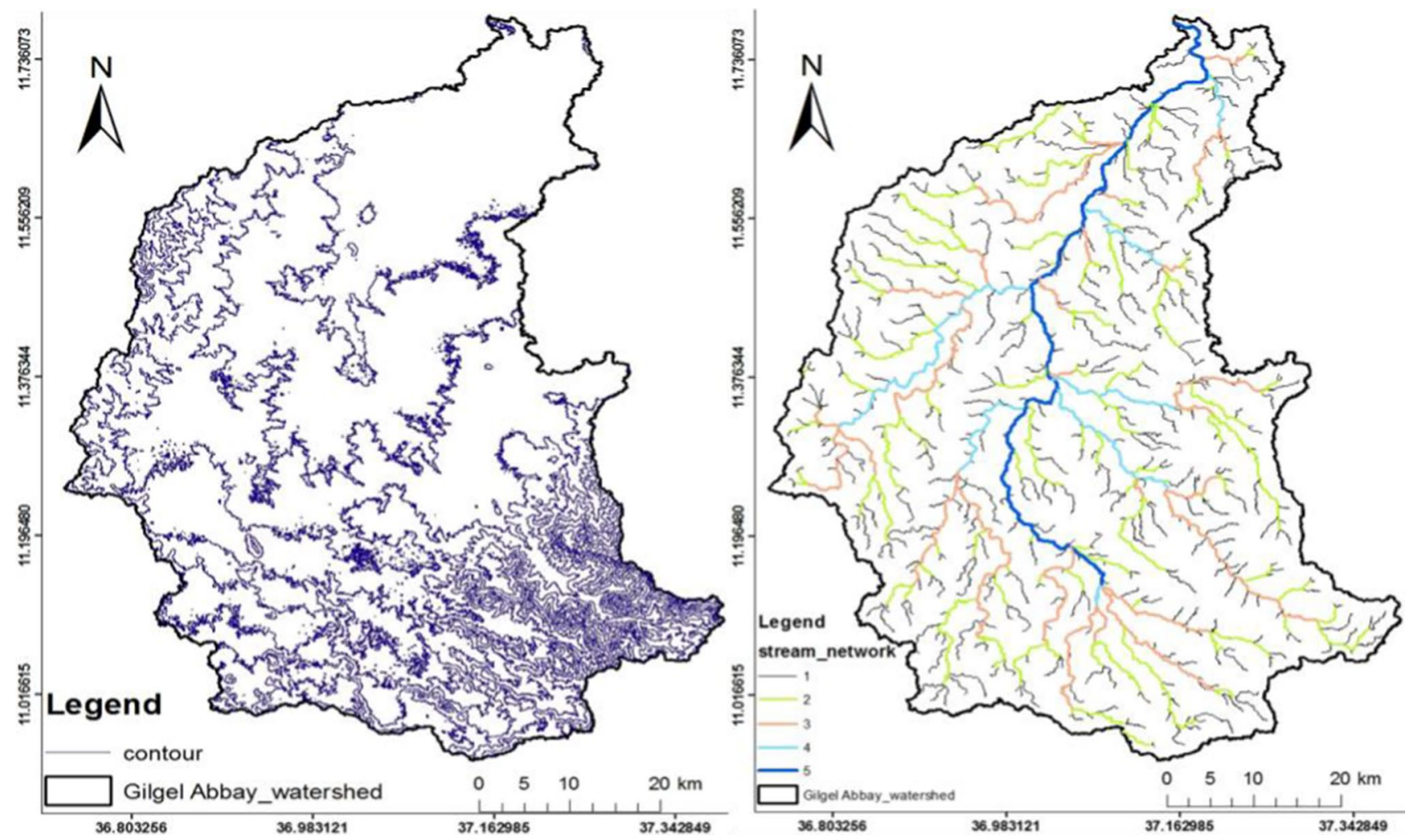

Fig. 3 Contour line and stream networks of the study watershed

\section{Linear aspects}

The linear aspects of morphometric analysis of basin including stream order, stream length, stream length ratio, and bifurcation ratio are discussed below.

\section{Stream order (So)}

The stream order or water body order is a positive whole number used in geomorphology and hydrology to indicate the level of branching in a river system. There are various types of stream ordering technique (Horton 1945), (Strahler 1952). Strahler's system which is slightly modified the Horton's method was used to analyze the stream order in this study. The smallest (un-branched) streams are first order and where the two first-order streams join together, they form second-order and two second-order streams come together to change to third order and so on, whereas two different levels of streams come together; they will remain as the highest one. The Gilgel Abay basin is the fifth-order stream. The total of 662 streams were identified, of which 511 streams are first order, 111 streams are second order, 30 are third order, 9 streams are fourth, and 1 stream is fifth order (Table 1). The study of properties of stream network is essential to understand basin hydrological process. Gilgel Abay streams are middle reach streams which host cold water fish species such as trout if well-shaded or fed by significant spring sources. Even though Lake Tana is one of fresh lakes and many communities livelihood is through fishing due to that Gilgel Abay is one major contributing stream, the Gilgel Abay is much more likely than headwater streams to be impacted by both point and non-point sources of pollution. The drainage networks of the watershed have nonlinear relationships as most drainage network property.

\section{Stream length $\left(S_{1}\right)$}

Stream length is also one of the most potential parameters to understand the hydrological features of the basin. Many number of streams with relatively small in length are observed in steep slope and finer texture of the basin. Longer length of streams is generally indicative of flatter catchment. Generally, cumulative length of stream segment is maximum in first order and decreases the length with increasing the stream order (Table 1). The total number and length of Gilgel Abay stream were determined with the help of GIS 10.1 software. Stream characteristics of the watershed agreed with Horton's law of stream length, which states that the cumulative stream length tends to form a geometric series beginning with the mean segment length of first order and increase according to the constant length ratio (Horton 1932, 1945). The relationship between stream order 
Table 1 Linear aspect of the drainage network of the study area

\begin{tabular}{lllll}
\hline Stream order & Stream number & Stream length $(\mathrm{km})$ & Mean stream length (km) & $\begin{array}{l}\text { Cumulative } \\
\text { stream length } \\
(\mathrm{km})\end{array}$ \\
\hline 1 & 511 & & 2.21 & 2.21 \\
2 & 111 & 1127.1 & 4.88 & 11.63 \\
3 & 30 & 541.46 & 14.26 & 32.97 \\
4 & 9 & 348.75 & 106.66 & 139.62 \\
5 & 1 & 128.34 & & Mean bifurcation \\
Total & 662 & 106.66 & & ratio \\
Bifurcation ratio & & 2252.31 & & 5.16 \\
First order/second order & Second order/third order & Third order/fourth order & Fourth order/fifth order \\
4.60 & 3.70 & 3.33 & 9.00 &
\end{tabular}

and their cumulative length examined is depicted in Table 1. The change of streams between orders indicates that flowing is from high altitude, lithological variation and from steep slope to flatter land.

\section{Bifurcation ratio $(\mathrm{Br})$}

Bifurcation ratio is the basic parameter to explain the stream patterns of the basin as the patterns are highly linked with the watershed topology and climate condition. It indicates the shape of the basin and understanding the runoff behavior of the watershed, and it is a useful measure to flooding prone area. High bifurcation ratio indicates short time of concentration, and the probability of flooding will be high. The Gilgel Abay mean bifurcation ratio is 5.16 which is larger than standard bifurcation ratio (Table 1). The bifurcation ratio varies between 2 in flat and rolling surface to 4 or 5 in mountainous or highly dissected drainage basins. Minimum bifurcation ratio indicates that the basin is more flat or rolling drainage basins. The study watershed is highly susceptible to flooding due to high bifurcation ratio.

\section{Aerial aspects}

It deals with the total projected area with upon contributing overland flow to the channel segment in different stream order. It comprises drainage density, drainage texture, stream frequency, form factor, circularity ratio, and elongation ratio.

\section{Drainage density (Dd)}

Drainage density is one of the parameters which affects the hydrological process of the watershed. It is defined as the ratio of the total length of the stream over the contributing area (Pallard et al. 2008, 2009). Drainage density potentially affects both time of concentration and magnitude of the flow. High drainage density implies increase in flood peaks, whereas there is decrease in flood level in low drainage density (Pallard et al. 2009). It is because long concentration time allows more opportunities to infiltrate and distributing through time the flow. Generally drainage density and flood volume have direct relation. Drainage density of the study area is $0.6 \mathrm{~km}^{-1}$ (Table 2) indicating low drainage densities are observed. The moderate drainage density indicates the basin is highly permeable subsoil and vegetative cover (Nag 1998).

\section{Stream frequency (Fs)}

It is the total number of stream segments per unit area of the basin. Stream frequency is positive relation with drainage density. The stream frequency of the study watershed is 0.2 .

\section{Texture ratio $(\mathrm{T})$}

The watershed characteristics such as slope, soil type, climate, rainfall, vegetation, and infiltration capacity will affect the

Table 2 Arial aspects of the study area

\begin{tabular}{lll}
\hline Morphometric parameter & Symbol/formula & Result \\
\hline Area (sq. km) & $A$ & 3785.56 \\
Perimeter $(\mathrm{km})$ & $P$ & 564.8 \\
Drainage density $(\mathrm{km} / \mathrm{sq} \cdot \mathrm{km})$ & $\mathrm{Dd}=\sum \mathrm{Lu} / A$ & 0.6 \\
Stream frequency & $\mathrm{Fs}=\sum \mathrm{Nu} / A$ & 0.2 \\
Texture ratio & $\mathrm{T}=\sum N 1 / P$ & 1.17 \\
Basin length & $\mathrm{Lb}$ & 93 \\
Elongation ratio & $\mathrm{Re}=2 \sqrt{A / \pi} / \mathrm{Lb}$ & 0.49 \\
Circularity ratio & $\mathrm{Rc}=4 \pi A / P^{2}$ & 0.15 \\
Form factor ratio & $\mathrm{Rf}=A /(\mathrm{Lb})^{2}$ & 0.44 \\
\hline
\end{tabular}

where $\mathrm{Lu}=$ total stream length of all orders, $\mathrm{Nu}=$ total number of all orders, $\mathrm{N} 1=$ total number of first-order streams, $\pi=3.14$ 
texture ratio of the watershed. The more the drainage texture, the more will be dissection and erosion. It is the ratio of the total number of stream segment per perimeter of the watershed. The texture ratio of the Gilgel Abay watershed is 1.17 (Table 2). It is categorized as moderate in nature.

\section{Form factor (Ff)}

Form factor is essential to explain the flow property of drainage basin. It is computed by dividing basin area by square of the basin length. When the value of form factor decreases, the basin will come more elongated. The smaller the form factor with more elongated shape, low runoff will generate with long runoff duration, whereas rounded-shape watershed with high value of form factor experiences high runoff with short time of concentration and is highly sensitive to flooding. The maximum threshold value of form factor is less than 0.7854 (Waikar and Nilawar 2014). The form factor ratio value for this study area is 0.44 which indicates lower value of form factor and thus the basin is with low pick flow and longer duration due to elongated basin (Table 2).

\section{Circulatory ratio $(\mathbf{R c})$}

As other morphometric parameters, circulatory ratio is an helpful assessment to understand flood hazard. With increase in the Rc value, there is an increase in the flood level and susceptibility to flood hazards at pick time at the outlet of the basin. It is the ratio of the area of the basin to the area of the circle having same circumference as the basin perimeter (Miller 1953). The Rc value indicates the shape of the basin; when the Rc value increases, the shape of the basin becomes more rounded and short flow duration is high potential to flooding at the outlet point. The Rc value of the Gilgel Abay is 0.15 which indicates that the basin is elongated and less susceptible to flooding (see Table 2).

\section{Elongation ratio $(\mathrm{Re})$}

Re indicates the shape of the basin. It is ratio of diameter of a circle of the same area as the basin to the maximum basin length. When the Re value becomes increasing, the basin will be more circular and highly susceptible to flooding due to short time of concentration and vice versa. The Re value of the study area is 0.49 indicating the basin is an elongated and less probable to flooding as well as moderate to slightly steep slope.

\section{Conclusion}

GIS and remote sensing technique is a powerful tool to assess the morphometric parameter of basin hydrology. It helps to understand the basin hydrology to potential prioritization of sub-watershed, effective soil and water conservation work, natural resource management and flood risk analysis. The morphometric analysis was carried out in Gilgel Abay watershed in Lake Tana Basin, upper Blue Nile Basin. The result showed that the basin indicating susceptible to flooding and soil erosion at the upper part of the basin whereas more runoff is infiltrated and sediment deposited at the downstream part since it is gentle and high ground water potential is observed indicating slightly susceptible to flooding and soil erosion in downstream part of the watershed. Evaluation morphometric analysis of the basin using GIS and remote sensing helped us to understand terrain parameters such as infiltration capacity, runoff, lithology and relief which affect the hydrological process of the basin. More studies with high-resolution satellite data with the help of ground-based observed data will help us to better understand and design more effective watershed management system.

Funding The author(s) received no specific funding for this work.

\section{Declarations}

Conflict of interest The author declares that he has no conflicts of interest.

Open Access This article is licensed under a Creative Commons Attribution 4.0 International License, which permits use, sharing, adaptation, distribution and reproduction in any medium or format, as long as you give appropriate credit to the original author(s) and the source, provide a link to the Creative Commons licence, and indicate if changes were made. The images or other third party material in this article are included in the article's Creative Commons licence, unless indicated otherwise in a credit line to the material. If material is not included in the article's Creative Commons licence and your intended use is not permitted by statutory regulation or exceeds the permitted use, you will need to obtain permission directly from the copyright holder. To view a copy of this licence, visit http://creativecommons.org/licenses/by/4.0/.

\section{References}

Christopher O, Idowu AO, Olugbenga AS (2010) Hydrological analysis of Onitsha north east drainage basin using geoinformatic techniques. World Appl Sci J 11(10):1297-1302

Dutta D, Sharma J (2002) Watershed characterisation, prioritisation, development planning and monitoring remote sensing approach. ISRO

Horton RE (1932) Drainage-basin characteristics. EOS Trans Am Geophys Union 13(1):350-361

Horton RE (1945) Erosional development of streams and their drainage basins; hydrophysical approach to quantitative morphology. Geol Soc Am Bull 56(3):275-370

Miller VC (1953) Quantitative geomorphic study of drainage basin characteristics in the Clinch Mountain area, Virginia and Tennessee. Technical report (Columbia University Department of Geology); No. 3 
Nag S (1998) Morphometric analysis using remote sensing techniques in the Chaka sub-basin, Purulia district, West Bengal. J Indian Soc Remote Sens 26(1-2):69-76

Oyegoke S, Ifeadi C (2008) Relationship between Drainage Basin Area and stream length for River Gongola. Nigeria Environ Res J 2(1):23-27

Pallard B, Castellarin A, Montanari A (2008) A look at the links between drainage density and flood statistics. Hydrol Earth Syst Sci Discuss, 5(5)

Pallard B, Castellarin A, Montanari A (2009) A look at the links between drainage density and flood statistics. Hydrol Earth Syst Sci 13(7):1019

Rastogi R, Sharma T (1976) Quantitative analysis of drainage basin characteristics. J Soil Water Conserv India 26(1-4):18-25

Schumn S (1956) Evolution of drainage basins and slopes in bund land of Peth Amboy, New Jersey. Bull Geol Soc Am 67:597-646
Strahler AN (1952) Dynamic basis of geomorphology. Geol Soc Am Bull 63(9):923-938

Strahler AN (1964) Part II. Quantitative geomorphology of drainage basins and channel networks. Handbook of applied hydrology. McGraw-Hill, New York, pp 4-39

Waikar M, Nilawar AP (2014) Morphometric analysis of a drainage basin using geographical information system: a case study. Int $\mathbf{J}$ Multidiscip Curr Res 2:179-184

Publisher's Note Springer Nature remains neutral with regard to jurisdictional claims in published maps and institutional affiliations. 